\section{Educación Médica, camino de la excelencia}

Arcadi Gual Sala

Director de Educación Médica

\section{Educación Médica, the way of excellence}

Me complace presentar a los lectores de la revista Educación Médica (Educ Med) el nuevo formato de la revista. Durante sus 10 años de vida, lo que representa 40 números y 10 suplementos, hemos sido fieles al formato y a la estructura del primer número. En estos años, la estética, la moda y, sobre todo, las necesidades de los lectores se han ido transformando y por ello debemos adaptar la revista para hacerla más ágil, más dinámica, más accesible, más atractiva; en una palabra: más útil. A partir de este número Viguera Editores se ha hecho cargo del proyecto editorial con el que deseamos complacer tanto a los suscriptores como a los lectores puntuales de la revista.

No buscamos sólo un cambio de imagen, sino un acercamiento al lector. Durante el año 2008 pretendemos avanzar en diferentes cuestiones. Así, la revista dispondrá de una página web propia que permitirá un mayor acceso y una mayor interacción entre los lectores y Educ Med. Queremos estimular la participación de todos los profesionales relacionados con la educación médica -grado, posgrado y formación continuada- en la sección epistolar de la revista Educ Med para que siga siendo un foro respetuoso e imparcial de ideas, opiniones, comentarios y críticas a la realidad de la formación de los profesionales de las ciencias de la salud. Opiniones y críticas constructivas que podrían ser de utilidad si se difundieran más en todos los ámbitos relacionados con la formación de nuestros profesionales, especialmente entre los responsables de la gestión de la formación, tanto de las administraciones como de las instituciones académicas.

Pero todos los cambios de formato e incluso los estructurales no representarían nada sino estuviese en el ánimo de todos el incrementar la calidad tanto de la revista Educ Med como de
It gives me great pleasure to introduce readers of Educación Médica (Educ Med), the new format of the journal. Since it first appeared 10 years ago, and throughout the 40 issues and 10 supplements that have appeared in that time, we have remained faithful to the format and layout of the first issue. Over the years, tastes, trends and, above all, our readers' needs have changed and we therefore feel the journal needs to be adapted so as to make it more flexible, more $d y$ namic, easier to access, more appealing and, in short, more useful. As of this issue, Viguera Editores is now responsible for editing the journal, which we hope will satisfy both subscribers and occasional readers.

Our intention is not only to introduce a change of image but also to get closer to the reader. Throughout the year 2008 we aim to advance in a number of different matters. The journal will have its own website, which will make it easier to access and allow a greater degree of interaction between readers and Educ Med. We want to encourage all professionals who are somehow involved in medical education (at graduate, postgraduate and continuing education levels) to participate in the letters section of the journal Educ Med. By so doing we hope it will continue to serve as a meeting point where ideas, opinions, comments and criticism regarding the training of health science professionals can be exchanged in a respectful and open-minded manner. Such opinions and constructive criticism could be a valuable aid if they were disseminated more widely in all the spheres related to the training of our professionals. This would be especially true in the case of those responsible for training management, both in the different administrations and in academic institutions.

But all these changes in format and even the modifications involving the layout would be pointless without everybody's desire to improve the quality of both the journal Educ Med and medical education itself.
E-mail agual@ub.edu 
la propia educación médica. El área de conocimiento de la educación médica en nuestro entorno sociocultural ha de emprender el viaje a la excelencia como lo hizo hace unas décadas en el entorno anglosajón. En este viaje, tanto la revista Educ Med como la Fundación Educación Médica sólo pueden aportar un grano de arena; seriedad e imparcialidad en su gestión, información rigurosa y contrastada en la mejor evidencia científica, revisión por pares de los originales de la revista, pero poca cosa más. El camino de la excelencia es cosa de todos, profesores y alumnos, gestores y políticos, instituciones públicas y privadas. Nuestro tren ha salido con retraso, pero lo importante es no pararse, lo importante es llegar.
Medical education, as an area of knowledge within our sociocultural environment, must set out on the path to excellence, as it did several decades ago in the English-speaking world. On this journey, both Educ Med and the Fundación Educación Médica can only do their little bit, that is to say, contribute with serious and impartial management, rigorous information that has been checked against the best scientific evidence, and peer reviews of the original contributions to the journal, but not much else. Teachers and students, managers and politicians, public and private institutions -we must all commit ourselves to following the way to excellence. Our train has left a little late, but the important thing is to go on without stopping. The important thing is to reach our destination. 